\title{
NUMBER OF CELLS IN XYLEM, PHLOEM AND DORMANT CAMBIUM IN SILVER FIR (ABIES ALBA), IN TREES OF DIFFERENT VITALITY
}

\author{
Jožica Gričar ${ }^{1, *}$, Luka Krže ${ }^{2}$ and Katarina Čufar ${ }^{2}$
}

\begin{abstract}
SUMMARY
We investigated the anatomical structure of phloem and xylem growth rings as well as the dormant cambium in relation to vitality in 81 adult silver fir trees (Abies alba Mill.). Specifically, we investigated the number of cells produced in the current phloem growth ring (PR), xylem growth ring (XR) and their ratio, the number of cells in the dormant cambium (CC), and the structure of the PR, which included characterisation of the early phloem (EP), the late phloem (LP), and the presence, absence, and continuity of tangential bands of axial parenchyma (AP). EP was relatively stable with respect to number and types of cells as PR width changed, but LP was quite variable. The CC of more vital trees produced more xylem than phloem cells. The ratio of XR to PR number decreased with decreasing vitality of trees and in the most severely affected trees ( $4 \%$ of the study group), more cells were formed in the PR than in the XR. The number of cells in phloem, xylem and dormant cambium is positively correlated. The use of width and structure of phloem and the ratios between PR, XR and CC can provide information on tree conditions and, consequently, can be a useful tool for forest management.
\end{abstract}

Key words: Silver fir (Abies alba), phloem, xylem, cambium, sieve cells, tracheids, tree vitality, dormancy.

\section{INTRODUCTION}

The width and structure of wood (secondary xylem) archives the effects of current and past factors on tree growth. Numerous studies exist on xylem width and structure (e.g. Schweingruber 1986; Larson 1994; Wimmer 2002), whereas similar studies on secondary phloem are rare (e.g. Fink 1986).

The cambium of temperate-zone tree species is normally inactive in winter, when the number of cambial cells is reduced (Lachaud et al. 1999; Larcher 2003). However, the number of cambial cells depends on several other factors, such as tree species, tree age, part of the tree, and tree vigour and vitality (Larson 1994). In spring, resumption of cell divisions in the cambium results in an increase in the number of cambial cells.

1) Department of Yield and Silviculture, Slovenian Forestry Institute, Večna pot 2, SI-1000 Ljubljana, Slovenia [E-mail: jozica.gricar@gozdis.si].

2) University of Ljubljana, Biotechnical Faculty, Department of Wood Science and Technology, Rožna dolina, Cesta VIII/34, SI-1000 Ljubljana, Slovenia.

*) Corresponding author [jozica.gricar@gozdis.si].

Associate Editor: Barbara Lachenbruch 
The widths of the xylem and phloem increments are determined by the length of the period of cambial activity and the rate of cambial cell division. In normal conditions, the cambium produces more xylem than phloem cells (Panshin \& DeZeeuw 1980; Larson 1994; Plomion et al. 2001).

The rate of phloem formation is fairly stable throughout the growing season and is little affected by changes in growing conditions, whereas the formation of xylem is highly subject to environmental and climatic factors (Alfieri \& Evert 1968; Panshin \& DeZeeuw 1980; Gričar 2007; Gričar \& Čufar 2008). In trees with diminished vitality, xylem production is reduced and, consequently, the ratio between the xylem and the phloem increment becomes progressively smaller (Panshin \& DeZeeuw 1980; Larson 1994; Kozlowski \& Pallardy 1997; Plomion et al. 2001).

Silver fir (Abies alba) decline has been observed in many European countries, including Slovenia, since about 1950. In declining trees, researchers have documented a reduction in cambial production (particularly towards the xylem) and a shorter period of cambial activity prior to visible signs of crown damage (i.e. Bauch 1986; Fink 1986; Schweingruber 1986; Torelli et al. 1986; Dobbertin 2005). The silver fir decline, which is still not satisfactorily explained, is believed to result from complex interaction of numerous factors, such as drought, frost, pollution, competition among trees, soil acidification, inappropriate silvicultural treatments, insects, pathogens, etc. (e.g . Schütt 1977; Innes 1993, Levanič 1996). Due to this decline, the relative proportion of silver fir trees in Slovenian forests is expected to continue to decrease in the future (Boncina et al. 2003).

Declining trees have reduced vitality, which can be seen through the alterations in the condition of the crown, bud growth, and growth of the stem (radial and height) and root system, and increased electrical resistance of the cambium (Dobbertin 2005). Tree vitality is the dynamic ability of a tree to grow under the present conditions. Vigour, on the other hand, is the genetically derived capacity of the tree to resist strain (Shigo 1986). Vigour determines the potential power against any threats to survival, and is not, therefore, changeable. The resistance of a tree to external stress is an important criterion for its vitality condition (Dobbertin 2005). The vitality of a tree decreases as stress persists and as the capacity of the tree to survive diminishes. Irreversible damage or tree death can occur (Dobbertin 2005). The hypothetical optimal tree vitality is not known; only the minimum vitality (i.e. tree death) can be identified. Reduced xylem increments, as one of the first indicators of decreased tree vitality, are very useful for reconstruction of past tree vitality and evaluation of mortality risk (Bigler \& Bugmann 2004; Bigler et al. 2004). These assessments of individual tree vitality and accurate mortality predictions can be used in forest management to identify and selectively cut low-vitality trees, so as to release the remaining healthy trees (Bigler et al. 2004).

The relationship among number of cells in phloem, xylem and dormant cambium is still poorly understood. We hypothesise that the structure and width of the phloem increments, the ratio between the phloem and xylem increments and the width of the dormant cambium will reflect the health condition of the tree. More vital trees are expected to have much wider xylem than phloem increments, whereas in declining trees the ratio between xylem and phloem will decrease. The aims of the current research 
were threefold: 1) to study the structure of the phloem growth rings (PR) in silver fir (Abies alba) in relation to their width, 2) to determine the ratio between width of PR and width of xylem growth rings (XR) formed in the same year, and 3) to investigate the relation between the number of cells in the PR and XR and in the dormant cambium (CC) in trees of different vitality.

\section{MATERIAL AND METHODS}

The silver fir (Abies alba Mill.) trees were located in an Abieti-fagetum dinaricum mixed forest at Ravnik, Slovenia (approx. 45 $52^{\prime} \mathrm{N}, 14^{\circ} 16^{\prime} \mathrm{E}$, elevation 500-700 m). The studied trees were dominant or co-dominant, with an age of 150-180 years and a DBH greater than $50 \mathrm{~cm}$. The trees belonged to a population of 269 mature trees monitored from 1987 to 2007 (Čufar 1990; Torelli et al. 1999; Gričar \& Čufar unpublished). The health condition of the trees was assessed by determining the crown status index (CSI) based on progressive needle loss (modified from Bosshard 1986) and cambial electrical resistance (CER) (Torelli et al. 1999). Trees were assigned to 3 categories: A: trees with a full crown and productive cambium; B: trees with intermediate characteristics, and $\mathrm{C}$ : trees with a sparse crown and suppressed cambium following the methods of Torelli et al. (1999). Since the beginning of the observations, a relatively high percentage of class $C$ trees have died, and this trend continued even in the last decade when conditions of silver fir in Slovenia generally were improving. The trees were revisited at regular time intervals (3-4 years) to verify their status, with the last observation in the autumn of 2007.

For this study, we prepared microscopic slides of 81 trees of either vitality class A or vitality class C. Intermediate trees (class B) were not considered in this study due to their relatively low abundance in the forest. Slides were made from sample blocks $(0.5 \times 0.5 \times 1 \mathrm{~cm})$ containing the inner phloem, cambium and outer xylem taken from living trees at $1.3 \mathrm{~m}$ above ground during the dormant seasons of 1999 to 2003. The material extracted from the trees was immediately fixed in FAA (formalin-acetic acidethanol solution), and dehydrated in a graded series of ethanol (30\%,50\% and $70 \%)$ after one week. Permanent transverse sections ( $25 \mu \mathrm{m}$ thick) were prepared on a Leica SM 2000R sliding microtome with steel knives. Sections were stained with safranin ( $0.5 \%$ in $95 \%$ of ethanol) and astra blue ( $0.5 \%$ in $95 \%$ of ethanol) and finally mounted in Euparal. The sections were examined with a Nikon Eclipse E800 light microscope (bright-field and polarised light) using a Lucia G 4.8 image analysis system.

We analysed the dormant cambium and adjacent latest formed growth rings of phloem and xylem (Fig. 1a). The radially narrow cambial cells had thin primary cell walls that stained blue. The phloem cells were identified by unlignified, blue-stained secondary cell walls, which exhibited birefringence in polarised light. The cell lumina of the axial parenchyma in the phloem had dark stained contents (Fig. 1b). The xylem cells (tracheids) were characterised by lignified, red stained, thick secondary cell walls and empty lumina (Fig. 1a, b).

We divided the phloem into early phloem (EP) and late phloem (LP) (analogous to earlywood and latewood) on the basis of radial dimensions of sieve elements and even- 
tual presence of axial parenchyma cells (AP) that separates EP and LP. Next, for three radial files for each sample, we counted the number of cells in the dormant cambium (CC) and within the last formed XR and PR adjacent to the cambium. For the PR, we distinguished between cells in the EP and the LP. We also noted the presence, absence, and connectivity (continuous or discontinuous) of the first and second tangential bands of AP in the phloem.

We divided the trees into three groups, based on the ratio of number of cells in the $\mathrm{PR}: \mathrm{XR}$. For each of these groups we then summarised the anatomical structure of the $\mathrm{PR}$, the number of cells in the PR and the $\mathrm{XR}$ and the relation between $\mathrm{CC}$ and $\mathrm{PR}$ and $\mathrm{XR}$. Adjacent radial files of cells in the PR showed only minor variation in structure or number of cells (Gričar \& Čufar 2008).

The data were processed and calculated in Microsoft Excel and Systat v.11, and the graphs were drawn in SigmaPlot 9.0 software.

\section{RESULTS}

Microscopic examination of cross sections revealed that the trees could be classified into three groups on the basis of the ratios between the number of cells in the xylem (XR) and phloem (PR) growth rings (Table 1). Group 1 (43\% of the trees) contained trees with up to four times more cells in XR than in PR (Table 2). The trees in Group 2 (30\% of the trees) had a ratio between XR and PR from 4.0 to 10.0, and Group 3 (27\% of the trees) consisted of trees with a ratio between XR and PR greater than 10.0 (Table $3 \& 4$ ).

Table 1. Characteristics of tissues in three groups of trees with different ratios between xylem and phloem growth ring widths in terms of number of cells (XR:PR). XR $=$ xylem growth ring, $\mathrm{PR}=$ phloem growth ring, $\mathrm{AP}=$ axial parenchyma, $\mathrm{EP}=$ early phloem, $\mathrm{LP}=$ late phloem.

\begin{tabular}{cccccl}
\hline Group & Ratio XR:PR & No. of trees & \multicolumn{2}{c}{ No. of cell layers } & Structure of PR \\
& & $(\%)$ & XR & PR & \\
\hline 1 & $<4.0: 1$ & $34(43 \%)$ & $3-26$ & $3-7$ & $\begin{array}{l}\text { AP missing or discontinuous, } \\
\text { EP 1-5 or > 5 cells wide, } \\
\text { LP 1-3 cells wide or absent }\end{array}$ \\
2 & $(4.0-10.0): 1$ & $24(30 \%)$ & $25-80$ & $5-9$ & $\begin{array}{l}\text { AP discontinuous or continu- } \\
\text { ous, EP 2-4 cells wide } \\
\text { LP present }\end{array}$ \\
3 & $>10.0: 1$ & $23(27 \%)$ & $60-144$ & $6-12$ & \begin{tabular}{l} 
One or two bands of AP \\
\hline
\end{tabular} \\
\hline
\end{tabular}

\section{Group 1}

In almost half of the investigated silver firs (34 trees, $43 \%$ ), the ratio between XR and PR in terms of cell numbers was from 0.94:1 to 4.0:1 (Table 2). We found trees with narrower XR than PR only in this group. However, this occurred in only 3 trees 
of this group (9\%) (Table 2). The XR were on average 3-26 layers of cells wide and the PR 3-7 cell layers (Fig. 1b, c). In the narrower PR, composed of only 3-5 cell layers, the tangential band of axial parenchyma (AP), which separates early (EP) and late phloem (LP), was either absent or discontinuous (Fig. 1c). Furthermore, LP was

Table 2. Number of cells in early phloem, late phloem, total phloem and xylem produced in the same year, as well as characteristics of the first and second bands of axial phloem parenchyma for trees from Group $1 . \mathrm{EP}=$ early phloem, $1 \mathrm{AP}=$ first band of axial parenchyma, $\mathrm{LP}=$ late phloem, $2 \mathrm{AP}=$ second band of axial parenchyma, $\mathrm{PR}=$ phloem growth ring, $\mathrm{XR}=$ xylem growth ring, con $=$ continuous,$-=$ absent .

\begin{tabular}{|c|c|c|c|c|c|c|c|}
\hline Tree & $\begin{array}{c}\text { EP } \\
\text { (cell no.) }\end{array}$ & $1 \mathrm{AP}$ & $\begin{array}{c}\text { LP } \\
\text { (cell no.) }\end{array}$ & $2 \mathrm{AP}$ & $\begin{array}{c}\text { PR } \\
\text { (total } \\
\text { cell no.) }\end{array}$ & $\begin{array}{c}\text { XR } \\
\text { (cell no.) }\end{array}$ & $\begin{array}{l}\text { Ratio of } \\
\text { PR:XR }\end{array}$ \\
\hline 1 & $3-5$ & not con & $0-2$ & - & 5 & 5 & 0.94 \\
\hline 2 & $3-4$ & not con & $0-1$ & - & 4 & 3 & 0.75 \\
\hline 3 & $3-4$ & not con & $1-2$ & - & 5 & 4 & 0.80 \\
\hline 4 & $1-4$ & not con & $1-3$ & - & 4 & 5 & 1.15 \\
\hline 5 & $1-4$ & _- & $0-1$ & _- & 4 & 5 & 1.23 \\
\hline 6 & 5 & - & 0 & - & 5 & 7 & 1.40 \\
\hline 7 & 4 & - & 0 & - & 4 & 6 & 1.50 \\
\hline 8 & 4 & - & 0 & - & 4 & 6 & 1.50 \\
\hline 9 & $3-5$ & not con & $0-1$ & - & 5 & 8 & 1.71 \\
\hline 10 & 4 & - & 0 & - & 4 & 6 & 1.73 \\
\hline 11 & 5 & - & 0 & - & 5 & 8 & 1.79 \\
\hline 12 & $3-4$ & not con & 0 & - & 4 & 8 & 1.85 \\
\hline 13 & $3-5$ & not con & $0-1$ & - & 5 & 9 & 1.87 \\
\hline 14 & $3-5$ & not con & $0-1$ & - & 5 & 10 & 1.88 \\
\hline 15 & 4 & - & 0 & - & 4 & 7 & 2.00 \\
\hline 16 & 5 & - & 0 & - & 5 & 10 & 2.00 \\
\hline 17 & $2-4$ & not con & $0-2$ & - & 5 & 10 & 2.07 \\
\hline 18 & $2-4$ & not con & $0-1$ & - & 4 & 8 & 2.08 \\
\hline 19 & 4 & - & 0 & - & 4 & 8 & 2.09 \\
\hline 20 & 2 & con & 0 & - & 3 & 7 & 2.20 \\
\hline 21 & 3 & - & 0 & - & 3 & 7 & 2.63 \\
\hline 22 & $2-3$ & not con & $2-3$ & - & 6 & 17 & 2.86 \\
\hline 23 & $3-4$ & con & $1-2$ & - & 6 & 18 & 2.89 \\
\hline 24 & $3-4$ & con & $1-2$ & - & 6 & 17 & 2.94 \\
\hline 25 & $3-5$ & not con & $0-1$ & _- & 5 & 15 & 3.00 \\
\hline 26 & $1-2$ & con & $1-2$ & - & 5 & 15 & 3.00 \\
\hline 27 & $2-3$ & con & $2-3$ & - & 7 & 21 & 3.00 \\
\hline 28 & $1-2$ & con & $1-2$ & - & 5 & 16 & 3.13 \\
\hline 29 & $2-3$ & not con & $2-3$ & - & 6 & 19 & 3.17 \\
\hline 30 & 6 & - & 0 & - & 6 & 19 & 3.35 \\
\hline 31 & $2-4$ & con & $2-4$ & - & 7 & 24 & 3.43 \\
\hline 32 & 3 & not con & 0 & - & 3 & 9 & 3.50 \\
\hline 33 & $2-3$ & con & $2-3$ & - & 6 & 21 & 3.50 \\
\hline 34 & $3-4$ & con & $2-3$ & - & 7 & 26 & 3.71 \\
\hline
\end{tabular}



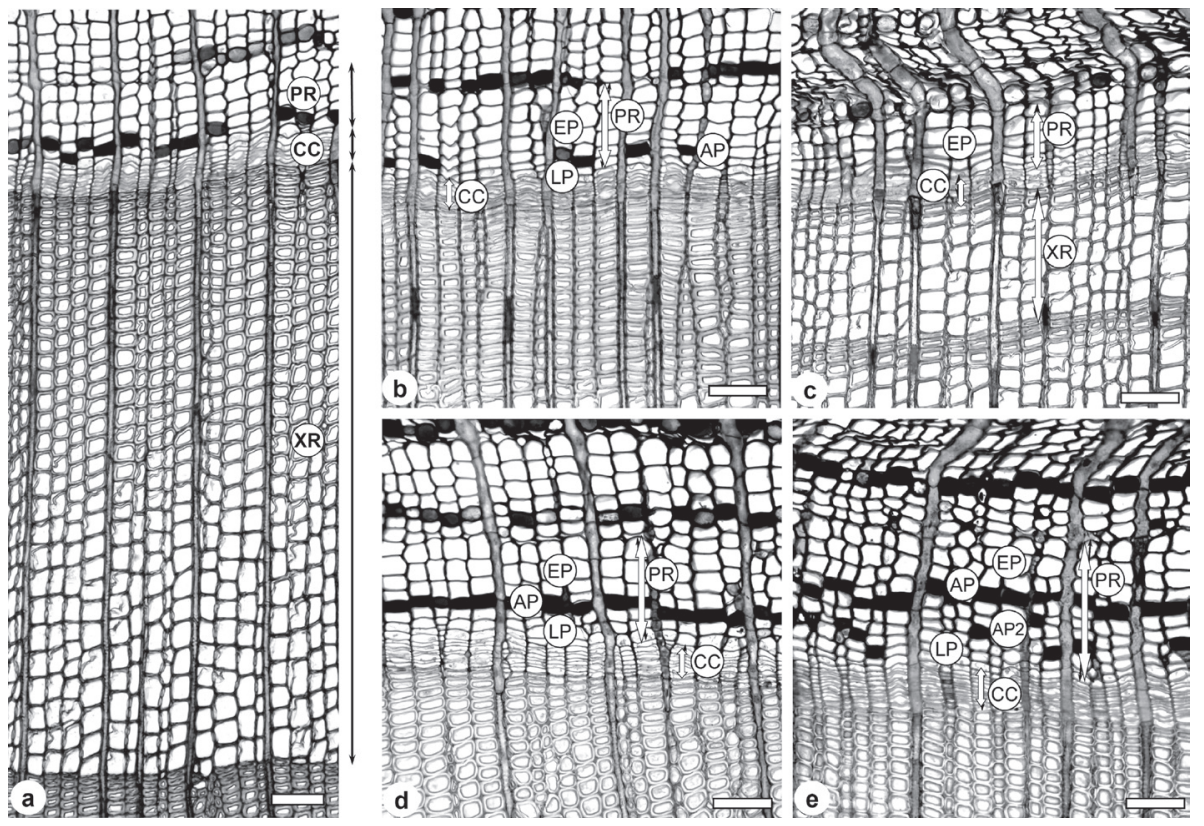

Figure 1. Transverse sections of xylem, cambium and different structural types of phloem in silver fir (Abies alba). - a: Typical cross section of a tree from Group 2 with a last formed xylem ring (XR) with approx. 30 layers of tracheids, cambium (CC) and last formed phloem growth ring (PR) with radially arranged sieve cells (empty lumina) and axial parenchyma (AP) with dark contents. - b: PR containing 1-3 cell layers of late phloem (LP) and 4 layers of early phloem (EP); the tangential band of AP dividing LP from EP is discontinuous. - c: PR without AP, containing only EP and no LP. - d: PR containing 1-3 cell layers of LP, 4 or more cell layers of EP and a continuous band of AP between them. - e: PR containing 4 or more layers of LP and an additional, second, discontinuous tangential band of axial parenchyma (AP2). - Scale bars $=100 \mu \mathrm{m}$.

mainly absent. The XR contained up to 10 cell layers and the $\mathrm{CC}$ (dormant cambium) was 3-5 cell layers wide (Fig. 1c). In cases in which the PR was 6-7 cell layers wide, the tangential band of AP was more or less continuous (Fig. 1d). The EP had 1-4 layers of sieve cells with wide radial dimensions and thin cell walls and the LP was composed of 1-3 layers of sieve cells with narrow radial dimensions and thick cell walls.

\section{Group 2}

In $30 \%$ of the investigated silver fir trees ( 24 trees), we detected a ratio between the XR and the PR from 4.0:1 to 10.0:1 (Table 3). The PR were on average 5-9 cell layers wide and the XR 25-80 cell layers. The EP was composed of 2-4 layers and the LP of 1-5 layers of sieve cells. The tangential band of AP was present in all trees from this group, but was discontinuous in narrower (4-5 cell layers) and continuous in wider (6-9 cell layers) PR (as seen in Fig. 1b, d; Table 3). 
Table 3. Number of cells in early phloem, late phloem, total phloem and xylem produced in the same year, as well as characteristics of the first and second bands of axial phloem parenchyma for trees from Group $2 . \mathrm{EP}=$ early phloem, $1 \mathrm{AP}=$ first band of axial parenchyma, $\mathrm{LP}=$ late phloem, $2 \mathrm{AP}=$ second band of axial parenchyma, $\mathrm{PR}=$ phloem growth ring, $\mathrm{XR}=$ xylem growth ring, con $=$ continuous,$-=$ absent .

\begin{tabular}{ccllcccc}
\hline Tree & EP & 1AP & LP & 2AP & PR & XR & Ratio \\
\hline 1 & $4-5$ & not con & $0-1$ & - & 5 & 20 & 4.00 \\
2 & $4-5$ & not con & $0-1$ & - & 5 & 20 & 4.00 \\
3 & $2-3$ & con & $2-3$ & - & 6 & 25 & 4.17 \\
4 & $2-3$ & con & $2-3$ & - & 6 & 28 & 4.67 \\
5 & $2-3$ & con & $2-3$ & - & 6 & 28 & 5.00 \\
6 & $3-4$ & con & $3-4$ & - & 8 & 51 & 6.38 \\
7 & $4-5$ & not con & 0 & - & 5 & 26 & 5.20 \\
8 & $3-4$ & con & $2-3$ & - & 7 & 37 & 5.29 \\
9 & $2-3$ & con & $2-3$ & - & 6 & 32 & 5.33 \\
10 & $2-4$ & not con & $0-1$ & - & 4 & 24 & 5.54 \\
11 & $3-4$ & con & $3-4$ & - & 8 & 46 & 5.75 \\
12 & $2-3$ & con & $2-3$ & - & 6 & 37 & 6.17 \\
13 & $2-4$ & con & $1-2$ & - & 6 & 37 & 6.17 \\
14 & $2-3$ & con & $2-3$ & - & 6 & 39 & 6.50 \\
15 & $2-4$ & con & $1-2$ & - & 6 & 40 & 6.67 \\
16 & $3-4$ & con & $2-3$ & - & 7 & 46 & 6.85 \\
17 & $3-4$ & not con & $1-2$ & - & 5 & 38 & 7.60 \\
18 & $3-4$ & con & $5-6$ & - & 9 & 80 & 8.88 \\
19 & $3-4$ & con & $2-3$ & - & 7 & 54 & 8.10 \\
20 & $2-3$ & con & $3-4$ & - & 7 & 59 & 8.44 \\
21 & $2-3$ & con & $2-3$ & - & 6 & 51 & 8.50 \\
22 & $3-4$ & con & $4-5$ & - & 9 & 80 & 8.89 \\
23 & $3-4$ & con & $3-4$ & - & 8 & 75 & 9.43 \\
24 & $2-3$ & con & $2-3$ & - & 6 & 57 & 9.38 \\
\hline & & & & & & & \\
\hline
\end{tabular}

\section{Group 3}

The XR was more than 10 times wider than the PR in $27 \%$ of the silver fir trees (23 trees) (Table 4). The PR were on average 6-12 and the XR 60-144 layers of cells wide. The tangential band of AP was present in all samples, and $33 \%$ of the trees in this group also contained an additional, second, discontinuous tangential band of AP in the LP (Fig. 1d, e). The EP consisted of 2-5 and the LP 2-7 cell layers.

\section{Relationship among number of cells in phloem, xylem and dormant cambium}

The investigated silver firs contained PRs consisting of 3-12 cell layers, with a more or less constant number of EP sieve cells (Fig. 2). In narrower PRs, composed of 2-6 layers of cells, the portion of EP was higher than that of LP; however, this ratio changed in the wider PRs composed of 7-12 cell layers. The XR was wider than the PR in all but three of the 81 trees sampled. Variability in the number of cells was higher in the 
Table 4. Number of cells in early phloem, late phloem, total phloem and xylem produced in the same year, as well as characteristics of the first and second bands of axial phloem parenchyma for trees from Group 3. EP = early phloem, 1AP = first band of axial parenchyma, $\mathrm{LP}=$ late phloem, $2 \mathrm{AP}=$ second band of axial parenchyma, $\mathrm{PR}=$ phloem growth ring, $\mathrm{XR}=$ xylem growth ring, con $=$ continuous, pres $=$ present,$-=$ absent .

\begin{tabular}{ccllllll}
\hline Tree & EP & 1AP & LP & 2AP & PR & XR & Ratio \\
\hline 1 & $2-4$ & con & $2-3$ & - & 6 & 60 & 10.00 \\
2 & $4-5$ & con & $5-6$ & pres & 11 & 110 & 10.00 \\
3 & $2-4$ & con & $2-3$ & - & 6 & 61 & 10.17 \\
4 & $3-4$ & con & $2-3$ & - & 7 & 71 & 10.14 \\
5 & $3-4$ & con & $1-3$ & - & 6 & 63 & 10.50 \\
6 & $3-4$ & con & $1-3$ & - & 6 & 66 & 11.00 \\
7 & $3-4$ & con & $5-7$ & pres & 11 & 121 & 11.00 \\
8 & $3-4$ & con & $1-2$ & - & 6 & 79 & 12.53 \\
9 & $3-4$ & con & $3-4$ & pres & 9 & 113 & 13.08 \\
10 & $3-4$ & con & $3-4$ & pres & 9 & 124 & 13.78 \\
11 & $2-3$ & con & $2-3$ & pres & 6 & 91 & 15.11 \\
12 & $3-4$ & con & $2-3$ & - & 7 & 81 & 11.52 \\
13 & $3-4$ & con & $1-2$ & - & 6 & 87 & 15.41 \\
14 & $3-4$ & con & $3-4$ & pres & 8 & 122 & 15.87 \\
15 & $4-5$ & con & $5-6$ & pres & 12 & 177 & 14.75 \\
16 & $3-4$ & con & $3-4$ & - & 8 & 130 & 16.25 \\
17 & $2-3$ & con & $3-4$ & - & 7 & 114 & 16.29 \\
18 & $3-4$ & con & $2-3$ & - & 7 & 110 & 16.55 \\
19 & $3-4$ & con & $3-4$ & - & 8 & 106 & 13.25 \\
20 & $3-4$ & not con & $3-4$ & - & 7 & 89 & 12.71 \\
21 & $2-3$ & con & $3-4$ & - & 7 & 125 & 17.86 \\
22 & $3-4$ & con & $3-4$ & pres & 8 & 144 & 18.00 \\
23 & $2-3$ & con & $3-4$ & pres & 8 & 137 & 19.52 \\
\hline
\end{tabular}

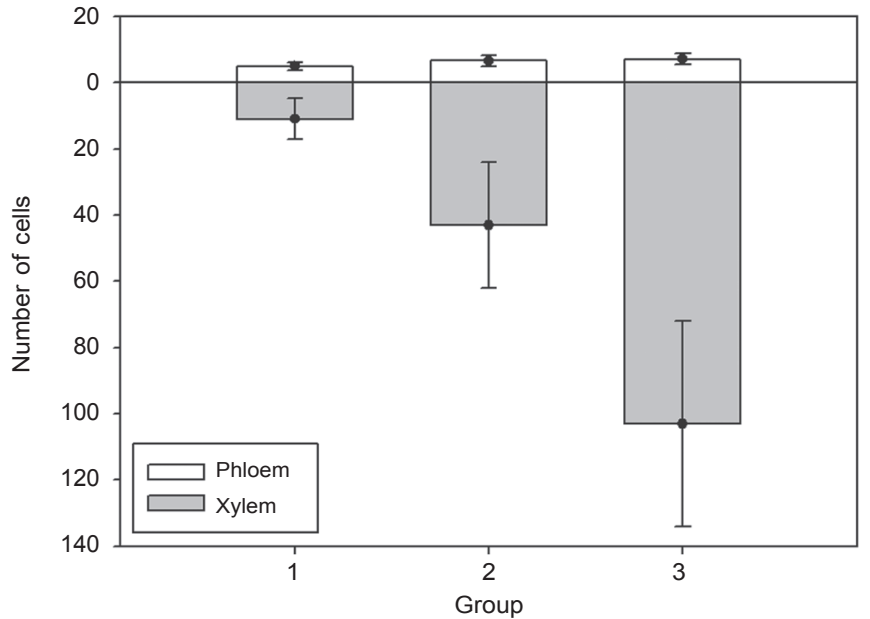

Figure 2. Number of cell layers in PR (white columns) and XR (gray columns) in silver firs from different groups. Error bars represent standard deviation. 

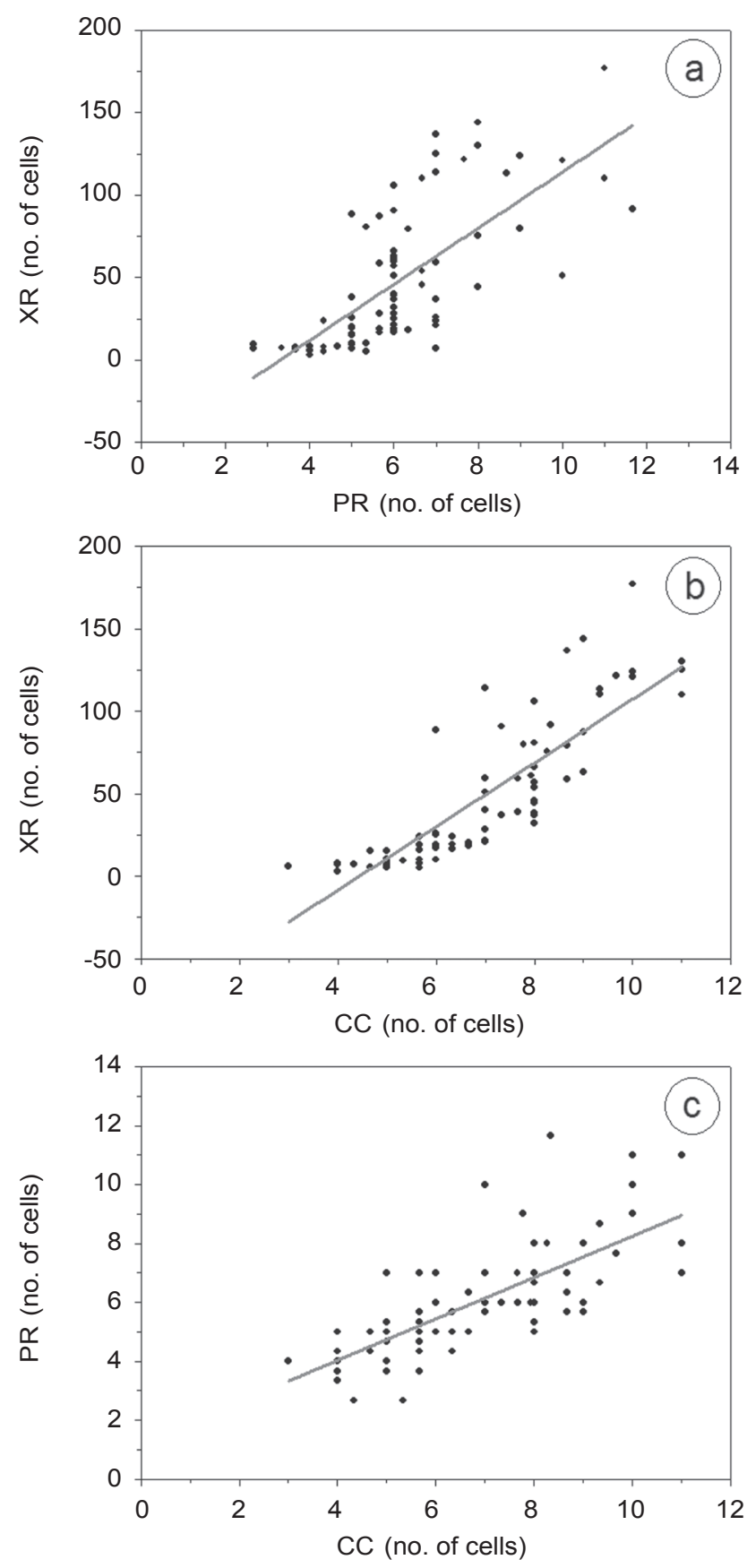

Figure 3. Relationship between number of cells in (a) the last formed phloem growth ring (PR) and the last formed xylem growth ring $(\mathrm{XR}), \mathrm{R}^{2}=0.51$; (b) the dormant cambium $(\mathrm{CC})$ and the last formed XR, $\mathrm{R}^{2}=0.71$; (c) the $\mathrm{CC}$ and the last formed $\mathrm{PR}, \mathrm{R}^{2}=0.53$. 
XR (3-144 layers) than in the PR (4-12 layers). In the investigated samples, the CC of silver fir consisted of 3-11 layers of cells. We found positive linear relationships between the number of cells of PR and XR $\left(R^{2}=0.51\right), C C$ and the $X R\left(R^{2}=0.71\right)$, and $\mathrm{CC}$ and the PR ( $\left.\mathrm{R}^{2}=0.53\right)($ Fig. 4).

\section{Vitality of trees in different groups}

Most of the trees from Group 1 were assessed as declining during the sampling (Table 5). Observation of trees after the sampling showed that more than half of the trees in Group 1 (62\%), with very narrow XR (only around 20 cell layers) and reduced phloem increment, died in the years after the sampling, confirming that the vitality of these trees had reached its minimum. The trees in Group 2 had relatively wide XR and PR and were classified as intermediate in vitality. Only $16 \%$ of the trees from Group 2 died in the years after sampling. Radial growth of the trees from Group 3 was intense on the xylem and phloem side, indicating that these trees were very productive. All of the trees in Group 3 have survived (Table 5).

Table 5. Crown status index (CSI) and cambial electrical resistence (CER) measurements in 1999 (Torelli et al. 1999), group based on the ratios between the number of cells in the xylem and phloem, and incidence of death after sampling (1999-2007, depending on individual). CSI and CER categories range from $\mathrm{A}$ (most healthy) to $\mathrm{C}$, and anatomical groups range from 1 (with narrow xylem and phloem increment) to 3 .

\begin{tabular}{ccccc}
\hline & & \multicolumn{2}{c}{$\begin{array}{c}\text { No. of trees in CSI } \\
\text { and CER group }\end{array}$} & \\
\cline { 3 - 4 } Ratio group & Total no. of trees in group & A & C & No. of dead trees \\
\hline 1 & 34 & 8 & 26 & 21 \\
2 & 24 & 17 & 7 & 4 \\
3 & 23 & 22 & 1 & 0 \\
\hline
\end{tabular}

\section{DISCUSSION}

Results based on an analysis of 81 adult silver firs of various vitality revealed that the anatomical structure and widths of the PR were closely related. The EP usually consisted of 2-4 layers of sieve cells, with wide radial dimensions and thin cell walls. Wider EP (5-7 cell layers) was only detected when the PR was composed solely of EP. A tangential band of AP normally separated the EP and LP. It was discontinuous in narrower $\mathrm{PR}$ and more or less continuous in wider PR. The structure of the LP varied in regard to the width of the PR. It was absent in extremely narrow PRs, or else was composed of 1-7 layers of sieve cells. In very wide PR (more than 8 cell layers), an additional, second, discontinuous tangential band of AP in the LP was observed. Variation in the anatomical structure and width of the PR in regard to growth conditions and vitality 
status of the silver fir trees has already been described by Holdheide (1951). He found that discontinuous or even absent tangential bands of AP and a reduced number of LP sieve cells are characteristics of trees growing under unfavourable conditions. Furthermore, Golinowski (1971) reported that the PR were wider and structurally different in younger silver firs than in mature trees.

In our previous study of experimentally controlled heating and cooling of the stem portion of adult Norway spruce (Picea abies) over the entire vegetation period, we found that the PR contained more late phloem cells if cambial activity ceased later (Gričar et al.2007). As observed in that study, the rate of production of phloem cells appeared to stay the same, regardless of whether the cambium was cooled, heated or untreated. On the xylem side, temperature had a stronger impact on cambial cell production at the very beginning of the growing season, while other factors not considered in that study seemed to prevail during latewood formation (Gričar et al. 2007). On the other hand, short-term experiments of heating (before cambial reactivation) and cooling (at the peak of cambial activity) over one month did not affect the widths and anatomical structure of the phloem increments (Gričar et al. 2006). These observations of the seasonal dynamics of phloem and xylem formation in Norway spruce and silver fir suggest that phloem formation is less subjected to fluctuations of environmental conditions during the growing season than xylem formation. Phloem formation might therefore be more endogenously controlled than xylem formation (Gričar \& Čufar 2008).

The formation of a phloem growth ring every year seems to be very important for the long-term survival of a tree (Esau 1939). Unlike the tracheids in the wood of conifers, which remain active and conduct water for years, the sieve cells in phloem maintain their ability to conduct assimilates only for a short period of time, which usually lasts for 1-2 years (Abbe \& Crafts 1939; Alfieri \& Evert 1968, 1973; Trockenbrodt 1990). However, if the phloem increment is extremely narrow and does not achieve sufficient width for efficient conductivity, older sieve cells may remain active a bit longer than usual (Holdheide 1951). In unfavourable conditions, when tree vitality decreases, the formation of phloem for the transport of assimilates is more important for the survival of a tree than xylem formation. In the tree under stress, phloem formation therefore has priority, whereas xylem formation can be considerably limited, with narrow, discontinuous or even missing rings. However, Bigler et al. (2004) showed that mature silver fir trees survive for about a decade if their annual production of xylem and phloem is limited significantly.

Inspection of the current condition of the investigated trees revealed that more than half of the trees $(62 \%)$ with a ratio between phloem and xylem increments lower than $4: 1$, with very narrow xylem (about 20 cell layers) and phloem only 3-5 cell layers wide, died in the years after the sampling of tissues for our analyses. Our results imply that the ratio between xylem and phloem, as well as the widths of xylem, phloem and dormant cambium, are related and indicate the health condition of a tree. They could therefore be used for assessment of the vitality condition of silver firs. This information could be beneficial in forest management practice for planning the cutting of non-vital trees with poor survival prognosis and to identify and promote healthy and productive ones. 


\section{CONCLUSIONS}

- The structure and widths of the PR are closely related in silver fir.

- The structure of EP is in general 2-5 layers of cells wide and is less dependent on tree vitality; whereas LP is subjected to higher alterations in width and type of cells.

- The occurrence and amount of AP varies in accordance with the width of PR: a) it can be absent or scarce when rings are very narrow; b) be present as one, more or less continuous, tangential band between EP and LP as observed in the majority of PR; or c) forming an additional, second, discontinuous tangential band in the LP of very wide rings.

- The cambium of vital trees normally produces more xylem than phloem cells. The ratio between XR and PR declines with decreased vitality of trees. Only in extreme cases can PR be wider than XR.

- The numbers of cells in phloem, xylem and dormant cambium are correlated in silver fir.

- Information on width and structure of PR, as well as on the relation between XR, PR and CC could provide additional criteria for determining tree vitality.

\section{ACKNOWLEDGEMENTS}

The work was funded by the Slovenian Research Agency, the Ministry of Higher Education, Science and Technology of the Republic of Slovenia within the framework of the Research Program Wood Science and Technology. The work in the field was enabled by the Farmland and Forest Fund of the Republic of Slovenia. We are grateful to Martin Zupančič from the Department of Wood Science and Technology, Biotechnical Faculty, for his great help with the collection of samples and microscopic slides.

\section{REFERENCES}

Abbe, L.B. \& A.S. Crafts. 1939. Phloem of white pine and other coniferous species. Bot. Gaz. 100: 695-722.

Alfieri, F.J. \& R.F. Evert. 1968. Seasonal development of the secondary phloem in Pinus. Am. J. Bot. 55: 518-528.

Alfieri, F.J. \& R.F. Evert. 1973. Structure and seasonal development of the secondary phloem in the Pinaceae. Bot. Gaz. 134: 17-25.

Bauch, J. 1986. Characteristics and response of wood in declining trees from forests affected by pollution. IAWA Bull. n.s. 7: 269-276.

Bigler, C. \& H. Bugmann. 2004. Assessing the performance of theoretical and empirical tree mortality models using tree-ring series of Norway spruce. Ecol. Mod. 174: 225-239.

Bigler, C., J. Gričar, H. Bugmann \& K. Čufar. 2004. Growth patterns as indicators of impending tree death in silver fir. For. Ecol. Manag. 199: 183-190.

Boncina, A., F. Gaspersic \& J. Diaci. 2003. Long-term changes in tree species composition in the Dinaric mountain forests of Slovenia. Forest Chron. 7: 227-232.

Bosshard, W. 1986. Kronenbilder mit Nadel- und Blattverlustprozenten. Eidgenössische Anstalt für das forstliche Versuchswesen. Birmensdorf.

Čufar, K. 1990. Električna upornost tkiv, prirastne značilnosti in odziv na poškodbe pri zdravih in obolelih jelkah (Electrical resistance of tissues, increment characteristics and response to injuries in healthy and diseased silver firs). Doctoral diss., University of Ljubljana, Ljubljana. $167 \mathrm{pp}$. 
Dobbertin, M. 2005. Tree growth as indicator of tree vitality and tree reaction to environmental stress: a review. Eur. J. Forest. Res. 124: 319-333.

Esau, K. 1939. Development and structure of the phloem tissue. Bot. Rev. 5: 373-432.

Fink, S. 1986. Microscopical investigations on wood formation and function in diseased trees. IAWA Bull. n.s. 7: 351-355.

Golinowski, W.O. 1971. The anatomical structure of the common fir (Abies alba Mill.) bark. 1. Development of bark tissues. Acta. Soc. Bot. Pol. 40: 149-181.

Gričar, J. 2007. Xylo- and phloemogenesis in silver fir (Abies alba Mill.) and Norway spruce (Picea abies (L.) Karst.). Studia forestalia Slovenica, Professional and Scientific Works, Ljubljana. 106 pp.

Gričar, J. \& K. Čufar. 2008. Seasonal dynamics of phloem and xylem formation in silver fir and Norway spruce as affected by drought. Russian J. Plant Physiol. 55: 538-543.

Gričar, J., M. Zupančič, K. Čufar, G. Koch, U. Schmitt \& P. Oven. 2006. Effect of local heating and cooling on cambial activity and cell differentiation in the stem of Norway spruce (Picea abies). Ann. Bot. 97: 943-951.

Gričar J., M.Zupančič, K. Čufar \& P. Oven. 2007. Regular cambial activity and xylem and phloem formation in locally heated and cooled stem portions of Norway spruce. Wood Sci. Technol. 41: 463-475.

Holdheide, W. 1951. Anatomie mitteleuropäischer Gehölzrinden (mit mikrophotographischem Atlas). In: H. Freund (ed.), Handbuch der Mikroskopie in der Technik: 193-365. Umschau Verlag, Frankfurt am Main.

Innes, J.L. 1993. Forest health: its assessment and status. Wallingford, Oxon, UK.

Kozlowsky, T.T. \& S.G. Pallardy. 1997. Growth control in woody plants. Academic Press, San Diego.

Lachaud, S., A.M. Catesson \& J.L. Bonnemain. 1999. Structure and functions of the vascular cambium. Life Sci. 322: 633-650.

Larcher, W. 2003. Physiological plant ecology: ecophysiology and stress physiology of functional groups. Ed. 4. Springer-Verlag, Berlin, Heidelberg, New York.

Larson, P.R. 1994. The vascular cambium. Springer-Verlag, Berlin, Heidelberg, New York.

Levanič, T. 1996. Dendrokronološka in dendroekološka analiza propadajočih vladajočih in sovladajočih jelk (Abies alba Mill.) v dinarski fitogeografski regiji (Dendrochronological and dendroecological study of dominant and co-dominant declining silver firs (Abies alba Mill.) in Dinaric phytogeographic region). Doctoral diss. University of Ljubljana, Ljubljana. 166 pp.

Panshin, A.J. \& C. DeZeeuw. 1980. Textbook of wood technology. Ed. 4. McGraw-Hill, New York.

Plomion, C., G. Leprovost \& A. Stokes. 2001. Wood formation in trees. Plant Physiol. 127: 15131523.

Schütt, P. 1977. Das Tannensterben: der Stand unseres Wissens über eine aktuelle und gefährliche Komplexkrankheit der Weisstanne (Abies alba Mill.). Forstw. Cbl. 96: 177-186.

Schweingruber, F.H. 1986. Abrupt growth changes in conifers. IAWA Bull. n.s. 7: 277-283.

Shigo, A.L. 1986. A new tree biology. Shigo \& Trees Associates, Durham, New Hampshire.

Torelli, N., K. Čufar \& D. Robič 1986. Some wood anatomical, physiological and silvicultural aspects of silver fir dieback in Slovenia. IAWA Bull. n.s. 7: 343-350.

Torelli, N., W.C. Shortle, K. Čufar, F. Ferlin \& K.T. Smith. 1999. Detecting changes in tree health and productivity of silver fir in Slovenia. Eur. J. Forest Pathol. 29: 187-197.

Trockenbrodt, M. 1990. Survey and discussion of the terminology used in bark anatomy. IAWA Bull.n.s. 11: 141-166.

Wimmer, R. 2002. Wood anatomical features in tree-rings as indicators of environmental change. Dendrochron. 20: 21-36. 